\title{
The Effect of Designed Geometry Teaching Lesson to the Candidate Teachers' Van Hiele Geometric Thinking Level
}

\author{
Gül Kaleli Yılmaz ${ }^{1}$ Timur Koparan ${ }^{2}$ \\ ${ }^{1}$ Bayburt Faculty of Education, Bayburt University, Bayburt, Turkey \\ ${ }^{2}$ Ereğli Faculty of Education, Bülent Ecevit University, Zonguldak, Turkey \\ Correspondence: Gül Kaleli Yılmaz, Bayburt University, Bayburt Faculty of Education, Bayburt, Turkey
}

Received: September 2, 2015

Accepted: September 17, $2015 \quad$ Online Published: October 10, 2015

doi:10.11114/jets.v4i1.1067

URL: http://dx.doi.org/10.11114/jets.v4i1.1067

\begin{abstract}
The aim of this study is to find out how designed Geometry Teaching Lesson affects candidate teachers' Van Hiele Geometric Thinking Levels. For that purpose, 14 weeks long study was performed with 44 candidate teachers who were university students in Turkey. Van Hiele Geometric Thinking Test was applied to candidate teachers before and after Geometry Teaching Lesson. Percentage, frequency and t-test were used for analyzing the data. When the data was investigated, it is seen that before Geometry Teaching Lesson, candidate teachers' geometric thinking levels and t- test points were really low, after lesson both their levels and t-test points made a considerable amount of progress. In this context, it can be said that designed geometry teaching lesson has an affect on upgrading candidate teachers' geometric thinking levels.
\end{abstract}

Keywords: geometric thinking, Van Hiele, candidate teachers

\section{Introduction}

The aim of teaching geometry is to provide an opportunity for the students in order to have critical thinking and problem solving ability and better understanding ability of mathematic topics by gaining high level of geometric thinking ability (MEB, 2000). To achieve this goal, students need to understand geometric terms, ratiocinate spatial problems and have cause and effect relationship between the features of geometric figures instead of memorizing definitions and theorems (Battista, 2002). These can only be done if students reach to the certain geometric thinking level.

The results of international exams such as TIMSS and PISA show that Turkey has underachievement about geometric topics (Eşme, 2008; Yayan \& Berberoğlu, 2009; Hurma 2011). When students' geometric achievement is examined, it is seen that students gather into subgroup or super group at university exam in Turkey, that is; some of the students answered most or all of the questions, the others answered several questions or none (Olkun \& Toluk, 2003; Hurma, 2011). While teaching geometric terms, not paying enough attention to the geometric topics and using wrong approaches and methods can be shown as the most important underlying causes of these failures (Olkun \& Aydoğdu, 2003).

As it is known geometric thinking which has specific concepts is a way of mathematical thinking. The development of geometric thinking is a formation which is process- based and contains definite stages. For that reason this process should be organized and planned very well in order to measure up the student's geometric thinking ability (Regina, 2000), rich learning environment should be offered to the students and education should be given taking account of their geometric thinking level. Hence, Usiskin (1982) indicated that some of the most important reasons to have difficulty in understanding geometry are not paying attention to the students' geometric thinking level during geometry teaching lessons and teaching geometry at the highest level not at students' level.

One of the most important studies about geometric thinking is The Geometric thinking Theory of Van Hiele. Van Hiele theory was propounded by Dutch mathematician Dina Van Hiele and his wife Pierre Marie Van Hiele in 1957. With this theory not only presented the reasons of geometry teaching problems but also suggested the solutions of these problems (Usiskin, 1982). At a result of the Euclid geometry study Hiele couple determined that all mathematical operation and terms, geometric thinking goes through certain phases. According to Van Hiele geometric thinking goes through five 
levels. Next chapters these phrases will be explained in detail but it can be sum up as it below:

1. Level (Recognition level) students are just interested in the image of the figure.

2. Level (Analysis Level Level) students can distinguish the features of figure

3. Level (Order Level) students can start to see the features relationship.

4. Level (Deduction Level) students can use theorem and axiom while doing geometric proof.

5. Level (Rigor Level students can study with different geometry (Usiskin, 1982).

In general, Van Hiele levels have these features:

- Levels are hierarchical

- Upgrading the level is up to teaching topics and methods not the age

- Each phrase has its own language, symbols and relationship

- Students will not measure up if geometry is thought at different transition periods.

As it is understand from the above features, it is not a natural process passing from one level to another at Van Hiele theory. Without giving proper education one cannot pass from one level to another, higher quality of education and student's effort to learn more things in a short time can speed up the passing from one level to another (Usiskin, 1982; Dindyal, 2007). According to Van Hiele geometric thinking level, averagely at a level of primary school student is at the first level and transition period of second level; at a level of secondary school student is at second level and transition period of third level; high school period students generally should be at third and fourth levels. However, this progress is completely based on education as Van Hiele indicated. Unless giving proper education, it is nearly impossible to reach at the $3^{\text {rd }}, 4^{\text {th }}$ and $5^{\text {th }}$ levels (Güven, 2006).

As is known, the geometric thinking levels of the future teachers who are today's candidate teachers are directly associated with the quality of their teaching. However; when the literature is examined, it is seen that the candidate teachers' geometry thinking levels are lower than expected and they are generally center of $1^{\text {st }}, 2^{\text {nd }}, 3^{\text {rd }}$ level (Şahin, 2008; Bal, 2012; Durmuş, Toluk \& Olkun, 2002). Besides, it is seen that there are some studies emphasizing students' geometric thinking level can be levelled up with well-conceived geometry lessons (Scally, 1991; Gigliotti, 1996; Bell, 1998; Breen, 2000; Güven, 2006; Tutak \& Birgin, 2008; Abdullah \& Mohamed, 2008; Meng, 2009; İdris, 2009; Anapa, Bağdat, Girit \& Karakoca, 2010). In this context, in order to level up candidate teachers' Van Hiele geometric thinking level, the content and implementation of geometry lessons should become clear during their undergraduate education.

\subsection{Van Hiele Geometric Thinking Levels}

As stated above, Van Hiele Geometric Thinking levels are consist of five levels; 'Recognition Level, Analysis Level, Order level, Deduction and ultimate level. These levels are explained in detail below (Güven, 2006, p.2):

\subsubsection{Recognition Level}

Students deal with the shape of the figure. The geometrical features cannot be noticed. Students understand the figures as a whole. Students specify, name and compare the figures with their appearance. At this level a square is just a square for kids, there is no special reason which makes the figure as a square. For example; the statements such as the tetragons of the square are equal or its angles are right do not make sense. At this level students are charmed by figures which is non-conversant feature. For example some students do not recognize upturned triangle as a triangle. They can recognize the square but they cannot comprehend that square is a rectangle at the same time.

\subsubsection{Analysis Level}

The students at this level can distinguish the features of the figure. However, the features are comprehended independently from each other. Students can count the features of the figure but they cannot link with these features with each other. They can explore the rules and features of the figure, fold and measure the figure and they can prove with an experimental way. For example; they can say that tetragons of the square are equal and it has four right angles.

1.1.3 Order Level

At this level, students start to see the features relationship between each other. Definitions and axioms are meaningful for the students but ordering levels have not been understood. For example; they can link to features and figures.' Each square is a rectangle at the same time' but they cannot organize necessary lists in order to proof this observation. At this level, they can refer to order level to contact with the figures. The students at this level can watch the proof but they cannot proof anything.

1.1.4 Deduction Level

At this level students can order the relationships. They can use theorem, axioms and definitions while proofing anything. 
They can identify necessary and enough conditions and use them for proof or inference. They can proof the other theorems via deduction while benefiting from proven theorems and axioms. At this level the features of the figures become independent from figure and object for the students. This level is high school period.

\subsubsection{Rigor Level}

The individuals at this level can interpret and practice the axioms and definition of Euclid geometry in out of Euclid geometry. They can recognize the differences and relationships between different axiomatic systems. They can see that systems as a working area.

\subsection{The Aim and Importance of the Research}

As is known an individual's geometric thinking level is an important determinant of understanding geometry topics. In order to understand geometry topics, geometric thinking level which the topics require is a prerequisite. As is emphasized in literature, generally candidate teachers have lower Van Hiele Geometric Thinking Level than they actually need to be (Şahin, 2008; Durmuş, Toluk \& Olkun, 2002). That is a distressing situation. That is because future teachers who are today's candidate teachers having lower geometric thinking level will also affect their students in a negative way. In order to prevent this situation, candidate teachers' education during undergraduate education has come into prominence. From this point of view, it is tried to teach necessary information and ability to the candidate teachers within the scope of 'Geometry Teaching Course' which is the elective course in Bayburt University in Turkey. It is aimed to find how geometry teaching course which is planned according to geometric thinking levels has an impact on candidate teachers' Van Hiele Geometric Thinking Levels. Within the scope of this purpose, sub problems were considered in this research.

- How does designed Geometry Teaching Lesson have an effect on candidate teachers' Van Hiele Geometric Thinking levels?

- How does designed Geometry Teaching Lesson have an effect on candidate teachers' Van Hiele Geometric Thinking Test points?

- How does designed Geometry Teaching Lesson have an effect on answering clinic interview questions correctly?

\section{Methodology}

\subsection{Research Method}

Mixed method enables using both quantitative and qualitative data at the same time and investigating same topic from different point of view (Johnson \& Onwuegbuzie, 2004; Creswell \& Plano Clark, 2007; Creswell, 2008). As both quantitative and qualitative data collecting tools are used to find out the candidate teachers' geometric thinking levels, using mixed method is found appropriate.

In this research mixed method is used and for quantitative data dimension Van Hiele Geometric Thinking Test is used. Van Hiele Geometric Thinking Test is used pre and post-test for candidate teachers. So same questions are used for pre and post-test. The data acquired from pre and post-test is analyzed with quantitative data analyzing method. Clinical interviews are used for qualitative dimension. It is aimed to find out candidate teachers' geometric thinking levels by evaluating both quantitative and qualitative data and determine the effect of Geometry Teaching Lesson on candidate teachers' levels.

\subsection{Implementation Process}

This research is carried out with the scope of Geometry Teaching Lesson. Geometry Teaching Lesson is not a compulsory lesson at all universities in Turkey. If a university wishes, it can have Geometry Teaching Lesson as an optional and it can also form the concept of the lesson. Geometry Teaching Lesson has been carried out 3 hours in a week and it has taken 14 weeks. Lesson content is presented below table.

Table 1. Content of Geometry Teaching lesson for 14 weeks

\begin{tabular}{ll}
\hline Weeks & Content of the Lesson \\
\hline $1^{\text {st }}$ week & Definition and structure of geometry. \\
$2^{\text {nd }}$ week & Geometric thinking and importance of it, Van Hiele Geometric Thinking Levels and teaching it. \\
$3^{\text {rd }}$ week & $\begin{array}{l}\text { The relation among the terms of point, line and plane. Term of angle, type of angles, congruent angles, congruent } \\
\text { axioms and teaching them. }\end{array}$ \\
$4-5^{\text {th }}$ weeks & $\begin{array}{l}\text { Definition of polygon and triangle terms, types of triangle, basic facts of triangles, similarity and congruence } \\
\text { theorem and teaching them. }\end{array}$ \\
$6-7^{\text {th }}$ weeks & Types and properties of quadrangle, teaching them. \\
$8-9^{\text {th }}$ weeks & Geometric shapes, teaching them. \\
$10^{\text {th }}$ week & Terms of circle and disk, angle and length theorem and teaching them. \\
$11^{\text {th }}$ week & Similarity and congruence and teaching them. \\
$12^{\text {th }}$ week & Transformation Geometry and teaching it. \\
$13-14^{\text {th }}$ weeks & Geometric objects, calculating the volume of surface area and teaching them. \\
\hline
\end{tabular}


All topics in table 1 were discussed practically with the students week by week during 14 weeks period. Lessons were based on constructivist approach and concrete materials (compass, ruler, protractor, setsquare, geometry board etc.) were used in each lesson. Teachers sometimes took advantages of dynamic software such as GeoGebra, Cabri 2 Plus during lessons. While drawing geometric shapes, teachers dealt with candidate teachers one-to-one, they were very sensitive in order to make all candidate teachers use compass, ruler, protractor, setsquare. Teachers gave a lot importance to how to teach as well as theoretic concept and each topic was supported with activity examples which were suitable for the teaching programme. Besides, how to proof some main geometric theorems was discussed during lesson and students were asked to give their own proof.

\subsection{The Participants}

The sample of the research consist of 18 men, 26 women totally 44 mathematic candidate teachers who are sophomores at Bayburt University in Turkey. Each of the candidate teachers has taken Geometry Teaching Class. Candidate teachers were coded as CT1, CT2, CT44.

\subsection{Data Collection Tools}

Van Hiele Geometric Thinking Test which was developed by Usiskin (1982) and translated Turkish by Baki (2006) and clinic interview as a data collecting tool are used in this research.

- Van Hiele Geometric Thinking Test (VHGTT) consists of 25 questions. In this test, there are 5 questions and each of them is related with Van Hiele Geometric Thinking Level. Exam duration is 35 minutes. Lee (2000) explained the questions related with each level of Van Hiele Geometric Thinking and the content of them in the below table (Tutak, 2008, p.110).

Table 2. The Questions about the Levels and Measured Ability

\begin{tabular}{lll}
\hline Levels & $\begin{array}{l}\text { The Number of } \\
\text { Questions }\end{array}$ & Measured Ability of Students \\
\hline 1. Level & $1-5$ & To recognize the geometric figures according to personal observation and ability. \\
2. Level & $6-10$ & To say the features of the figures by observation and drawing \\
3. Level & $11-15$ & To recognize the figures by analyzing figures' features and sort them \\
4. Level & $16-20$ & To understand the proof of the theorems \\
5. Level & $21-25$ & To understand the differences between axiomatic systems
\end{tabular}

As is seen in Table 2, questions between 1 and 5 are related with $1^{\text {st }}$ Level (Recognition level), questions between 6 and 10 are related with $2^{\text {nd }}$ Level (Analysis Level), questions between 11 and 15 are related with $3^{\text {rd }}$ Level (Order level), questions between 16 and 20 are related with $4^{\text {th }}$ Level (Deduction Level), questions between 21 and 25 are related with $5^{\text {th }}$ Level (Rigor level). A student needs to answer correctly at least three of these 5 questions in order to upgrade his level.

It is aimed to have information about candidate teachers' geometric thinking levels during clinic interview. For this purpose, this question; 'Is every parallelogram at the same time a trapezium?' was asked to the candidate teachers before and after the lesson. Researcher asked extra questions according to candidate teachers' answers. Clinical interview took 5 or 10 minutes.

\subsection{Data Analysis}

Both quantitative and qualitative analyses are going to be used in this research. Short information about how these analyses are going to be done is given below.

\subsubsection{Data Analysis of Van Hiele Geometric Thinking Test}

Van Hiele benefited from grading key which was developed by Usiskin (1982) while upgrading levels. According to Usiskin a student can get minimum 0, maximum 31 points from the VHGTT. Usiskin's grading key for Van Hiele Geometric Thinking Test is like that:

1. If at least three questions(between 1 and 5) are answered correctly: 1 point

2. If at least three questions(between 6 and 10) are answered correctly: 2 points

3. If at least three questions(between 11 and 15) are answered correctly: 4 points

4. If at least three questions(between 16 and 20) are answered correctly: 8 points

5. If at least three questions(between 21 and 25) are answered correctly: 16 points

If two of the questions among these groups are answered correctly: 0 point

As is understood from the grading, students need to answer correctly at least three of previous level questions in order to pass from one level to another. For example; a student who was able to answer three questions from 1 to 5 questions, two questions from 6 to 10, three questions from 11 to 15, gets 1 point from first level, 0 point from second level, 4 points from third level, totally gets 5 points. Although this student answered three questions correctly from Van Hiele's 
third level, he cannot take place in Van Hiele's third level because of that he were not able to answer correctly at least three of second level questions (Okumuş, 2011). In this study, the points got from Van Hiele Geometric Thinking Test which is performed as pre and post-test are analyzed with t-test. Thus, the differences according to both levels and points between pre and post-test are identified.

\subsubsection{Clinic Interview Data Analysis}

Pre and post clinic interview was recorded by a recorder than the data was written as a dialogue between researcher and teacher on computer. Based on these dialogues, it is inferred from candidate teachers' geometry knowledge and geometric thinking level. It is tried to determine the candidate teachers' geometric thinking levels and geometric knowledge based on these interviews.

Firstly, it is determined whether candidate teacher gave correct answer during interview or not. After than the reasons of giving correct or wrong answers were investigated. Each candidate teachers' answers were analyzed using by the criteria in Table 3. These criteria are formed with expert opinion. Two tables are formed according to teachers' correct and wrong answers during pre and post lesson (Table 8 and table 9). Researchers made an inference about candidate teachers' pre and post lesson levels based on these tables.

Table 3. Candidate Teachers' answers and Content of Their Answers

\begin{tabular}{lll}
\hline Feature & Answer & Content of Their Answers \\
\hline \multirow{2}{*}{$\begin{array}{l}\text { Every parallelogram is a } \\
\text { trapezium }\end{array}$} & $\begin{array}{l}\text { He/she knows the features of parallelogram and trapezium and } \\
\text { he/she can associate their features. }\end{array}$ \\
& No & $\begin{array}{l}\text { He/she knows the features of parallelogram and trapezium but } \\
\text { he/she cannot associate their features. } \\
\text { He/she does not know the features of parallelogram and trapezium. }\end{array}$ \\
\hline
\end{tabular}

Example interviews which give information about candidate teacher's general situation are presented in findings session.

\section{Findings}

\subsection{Findings about Candidate Teachers' Van Hiele Geometric Thinking Levels}

Van Hiele Geometric Thinking Test was applied to candidate teachers before and after Geometry Teaching Lesson. Analyzing the data obtained from both tests, candidate teachers' Van Hiele Geometric Thinking Levels were determined.

Table 4. Candidate Teachers' Van Hiele Geometric Thinking Levels

\begin{tabular}{llclc}
\hline Levels & \multicolumn{3}{c}{ Pre-lesson } & \multicolumn{2}{c}{ After-lesson } \\
& $\mathrm{f}$ & $\%$ & $\mathrm{f}$ & $\%$ \\
\hline Level 1 (Recognition) & 18 & 40.9 & - & - \\
Level 2 (Analysis) & 7 & 15.9 & 2 & 4.5 \\
Level 3 (Order) & 13 & 29.5 & 27 & 61.4 \\
Level 4 (Deduction) & 6 & 13.6 & 15 & 34.1 \\
Level 5 (Rigor) & - & - & - & - \\
Total & 44 & 100 & 44 & 100 \\
\hline
\end{tabular}

As is seen in the table 4, when Van Hiele Geometric Thinking Levels pre-test which was applied before Geometry Teaching lesson was examined, candidate teachers' levels were identified; 18 at Recognition, 7 at Analysis, 13 at Order, 6 are at Deduction Level. After Geometry Teaching lesson, it is determined that 2 of the candidate teachers are at Analysis Level, 27 at Order Level, 15 at Deduction Level. 


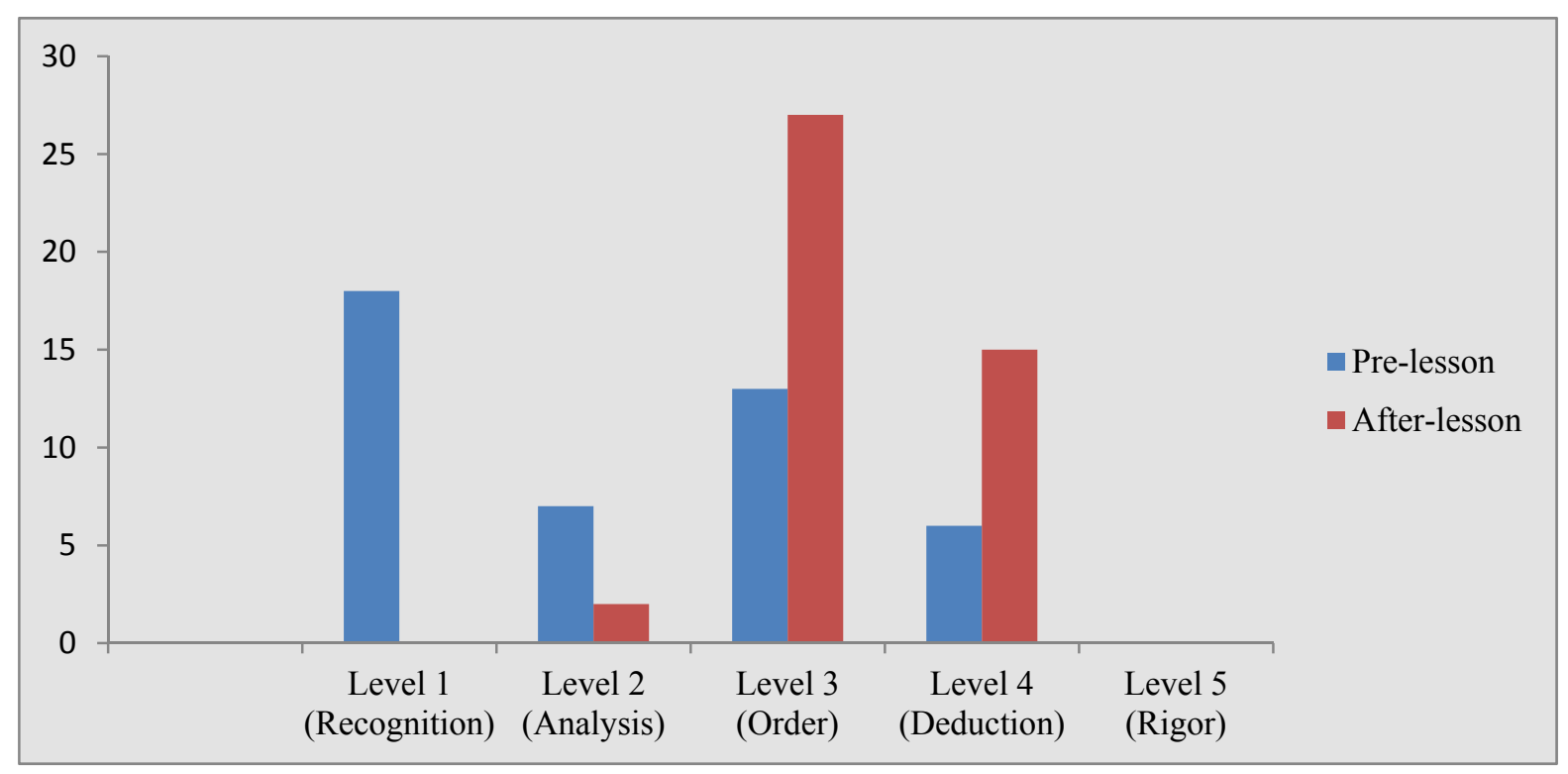

Figure 1. Comparing Van Hiele Geometric Thinking Levels

As is seen in the Figure 1 there was an improvement in candidate teachers' geometric thinking levels according to t-test applied to the candidate teachers after geometry teaching lesson. While most of the candidate teachers were at Recognition Level before lesson, after lesson there was no teacher at Recognition level. Beside, after lesson most of the candidate teachers gathering at Order and Deduction Levels drew attention. When the table and chart are examined, it is seen that after the lesson candidate teachers' geometric thinking levels were higher than before. T-test was applied in order to find out if this difference is meaningful or not.

Table 5. The result of Paired Sample t-test according to Van Hiele Geometric Thinking Level

\begin{tabular}{lllllll}
\hline Levels & $\mathrm{N}$ & Mean & Std. Deviation & $\mathrm{df}$ & $\mathrm{t}$ & $\mathrm{p}$ \\
\hline Pre-lesson & 44 & 2.159 & 1.12 & 43 & -8.333 & .000 \\
After- lesson & 44 & 3.295 & 0.55 & & & \\
\hline
\end{tabular}

As is understood that before geometry teaching lesson the average of candidate teachers' thinking level was 2.159, standard deviation 1.12, after lesson the average was 3.295, standard deviation 0.55. According to the result of dependent t-test, after lesson candidate teachers' geometric thinking levels were significantly differentiated to the benefit of them $\left[\mathrm{t}_{43}=-8.333, \mathrm{p}<.01\right]$. These findings are revealed that geometry teaching lesson was effective in developing candidate teachers' geometric thinking levels.

\subsection{Finding about the Candidate Teachers' Van Hiele Geometric Thinking Test Point}

As is emphasized before, no matter how the Van Hiele Geometric Test Points are high, in order to upgrade their level, candidate teachers must correctly answer at least 3 questions of that level. However, increasing rate of the test points is very important for the geometry teaching lesson's affect. As is emphasized in 'Data Analysis' session, anybody can get minimum 0 , maximum 31 points $(1+2+4+8+16=31)$ from VHGTT.

Table 6. VHGTT Pre and Post Test Point of Geometry Teaching Lesson

\begin{tabular}{|c|c|c|c|c|}
\hline \multirow[t]{2}{*}{ Points } & \multicolumn{2}{|c|}{ Pre-lesson } & \multicolumn{2}{|c|}{ After-lesson } \\
\hline & $\mathrm{f}$ & $\%$ & $\mathrm{f}$ & $\%$ \\
\hline 1 point & 3 & 6.8 & - & - \\
\hline 3 point & 6 & 13.6 & 2 & 4.5 \\
\hline 5 point & 9 & 20.5 & - & - \\
\hline 7 point & 12 & 27.3 & 24 & 54.5 \\
\hline 11 point & 1 & 2.3 & - & - \\
\hline 13 point & 4 & 9.1 & - & - \\
\hline 15 point & 6 & 13.6 & 15 & 34.1 \\
\hline 21 point & 2 & 4.5 & - & - \\
\hline 23 point & 1 & 2.3 & 3 & 6.8 \\
\hline
\end{tabular}

As is seen in Table 6, before Geometry Teaching Lesson candidate teachers VHGTT points could change among 1-23 while after lesson some teachers could get $3,7,15,23$ points. 


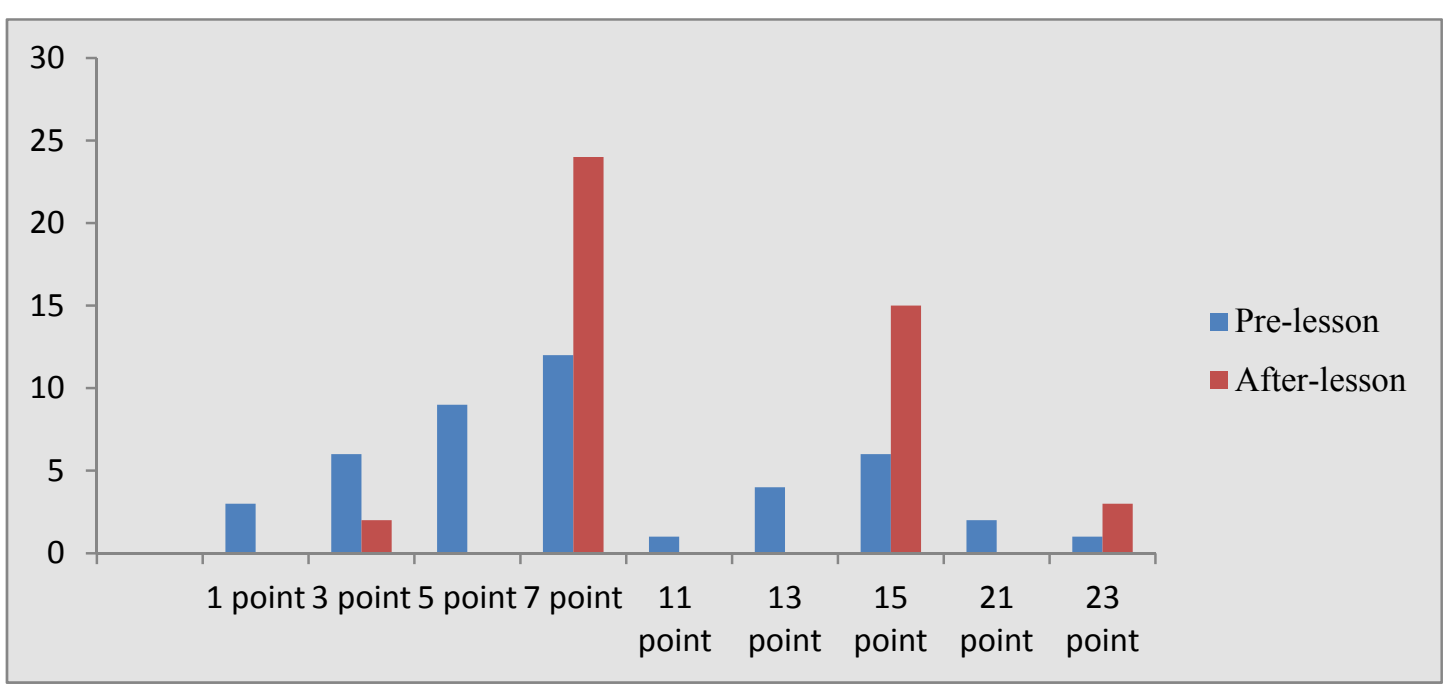

Figure2. Comparing Van Hiele Geometric Thinking Test Points

As is understood from the figure, both before and after the lesson, a major part of the candidate teachers got 7 points. Before the lesson, there were some candidate teachers who got 1, 3, 5 points while after the lesson the number of teachers getting low points was really few. When the chart and the table are investigated, it is seen that after the lesson candidate teachers' geometric thinking test points were higher than before. However, t-test was applied in order to understand if these differences could make sense or not.

Table 7. The Result of Paired Sample t-test according to VHGTT

\begin{tabular}{lllllll}
\hline Points & $\mathrm{N}$ & Mean & Std. Deviation & df & t & P \\
\hline Pre-lesson & 44 & 8.363 & 5.60 & 43 & -2.190 & .034 \\
After - lesson & 44 & 10.636 & 5.23 & & & \\
\hline
\end{tabular}

As is seen, before Geometry Teaching Lesson, the average of candidate teachers' geometric thinking test points was 8.363, standard deviation 5.60, on the other hands, after lesson the average was 10.636, standard deviation 5.23. According to Paired Sample t-test result, candidate teachers' geometric thinking test result were significantly differentiated to the benefit of geometry teaching lesson $\left[\mathrm{t}_{43}=-2.190, \mathrm{p}<.05\right]$. This finding prove that Geometry Teaching Lesson has an effect on increasing candidate teachers' Van Hiele Geometric Thinking Test points.

\subsection{Clinic Interview Findings}

Before lesson, 'Is every parallelogram at the same time a trapezium?' this question asked to candidate teachers. Pre lesson Clinic Interview Findings were analyzed and below chart was formed.

Table 8. Candidate Teachers' answers and Content of Their Answers in Pre Lesson

\begin{tabular}{lllll}
\hline Feature & Answer & Content of Their Answers & $\mathrm{f}$ & Total \\
\hline & Yes & $\begin{array}{l}\text { He/she knows the features of parallelogram and } \\
\text { trapezium and he/she can associate their features. }\end{array}$ & 6 \\
$\begin{array}{l}\text { Every } \\
\text { parallelogram is a } \\
\text { trapezium }\end{array}$ & No & $\begin{array}{l}\text { He/she knows the features of parallelogram and } \\
\text { trapezium but he/she cannot associate their features. }\end{array}$ & \\
& $\begin{array}{l}\text { He/she does not know the features of parallelogram } \\
\text { and trapezium }\end{array}$ & Total & 44 \\
\hline
\end{tabular}

As is seen in Table 8, during pre-lesson clinic interview 6 of the candidate teachers knew that each parallelogram is at the same time a trapezium. 38 candidate teachers thought that each parallelogram is not at the same time a trapezium. Although 20 candidate teachers knew the features of parallelogram and trapezium, they gave wrong answers because of not associating their features. 18 candidate teachers did not know the features of both geometric shapes so they gave wrong answer. The findings of clinic interview with CT13 are given below.

CT13 is one of the candidate teachers who knows the features of parallelogram and trapezium and associates their features. The findings of clinic interview with CT13 are given below (R: Researcher):

R: Is every parallelogram at the same time a trapezium? 
CT13: Yes.

R: Why? Explain please.

CT13: Parallelogram is a rectangle in which both pairs of opposite sides are parallel and equal in length. All of its angles are equal $\left(360^{\circ} / 4=90^{\circ}\right)$. Generally trapezium's lower and upper sides are parallel. The other sides no need to be parallel.

R: Good. How a parallelogram can be a trapezium?

CT13: If you pay attention, parallelogram has actually the same features with trapezium. Parallelogram is more special rectangle than trapezium. For that reason parallelogram is at the same time a trapezium.

As is understood, CT13 can know the features of parallelogram and trapezium and associate them. It can be said that $\mathrm{O} 13$ is at Order Level according to Van Hiele.

CT5 is one of the candidate teachers who can know the features of parallelogram and trapezium but cannot associate them. The findings of clinic interview with CT5 are given below:

R: Is every parallelogram at the same time a trapezium?

CT5: No, I think a parallelogram cannot be a trapezium.

R: Why?

CT5: Because parallelogram's all sides must be parallel but for trapezium opposite sides is parallel and that is enough.

R: Well, does opposite sides being parallel make an exception to trapezium rule?

CT5: Yes, in that case, it cannot be a trapezium.

R: Why? What is essential condition to be a trapezium?

CT5: Opposite sides must be parallel.

R: What else?

CT5: It must have four sides and be closed chain.

R: Okay, does not parallelogram have that features?

CT5: Yes, actually it has. Parallelogram has extra opposite parallel sides.

R: Thus, each parallelogram has the same features with trapezium, hasn't it?

CT5: Yes

R: Then, is every parallelogram at the same time a trapezium?

CT5: Yes, that is to say, every parallelogram is at the same time a trapezium.

As is seen, at the beginning CT5 thought that every parallelogram was not at the same time a trapezium. However, when the clinic interview was examined, it is seen that CT5 knew the features of trapezium. That is, CT5 knows the features of the shapes but he has problems with associating them. In this context, it can be said that CT5 is at Analysis Level according to Van Hiele. Nevertheless, during clinic interview CT5 changed his mind as a result of researcher guidance and he accepted this idea 'Every parallelogram is at the same time a trapezium'.

CT28 is one of the candidate teachers who thinks that 'Every parallelogram is not at the same time a trapezium'. The findings of clinic interview with CT28 are given below:

$\mathbf{R}$ : Is every parallelogram at the same time a trapezium?

CT28: No, it is not.

R: Why? Explain please.

CT28: A trapezium should be a trapezium not a regular shape

R: Does parallelogram have a regular shape.

CT28: Yes, it does. Its sides are parallel.

R: What does regular polygon mean? What features does it have?

CT28: Its sides shouldn't be tangent to an edge or corner.

R: Well, what does convex and concave polygon mean? 
CT28: Now, I don't remember.

As is seen, CT28 gave wrong answer due to having imperfect geometry knowledge. As well as he did not know features of the shapes, he mixed regular polygon with convex polygon. For this reason, it can be said that candidate teacher has not reached the second level according to Van Hiele. Naturally, as the candidate teacher had no idea about the features of the shapes, there is no expectation about associating them.

After 14 weeks Geometry Teaching Lesson, 'Is every parallelogram at the same time a trapezium?' again this question is asked to candidate teachers. After-lesson Clinic Interview Findings were analyzed and below chart was formed.

Table 9. Candidate Teachers' answers and Content of Their Answers in After Lesson

\begin{tabular}{lllll}
\hline Feature & Answer & Content of Their Answers & $\mathrm{f}$ & Total \\
\hline $\begin{array}{l}\text { Every } \\
\text { parallelogram is a } \\
\text { trapezium }\end{array}$ & Yes & $\begin{array}{l}\text { He/she knows the features of parallelogram and } \\
\text { trapezium and he/she can associate their features. }\end{array}$ & 39 & 39 \\
& No & $\begin{array}{l}\text { He/she knows the features of parallelogram and } \\
\text { trapezium but he/she cannot associate their } \\
\text { features. } \\
\text { He/she does not know the features of } \\
\text { parallelogram and trapezium }\end{array}$ & Total 44
\end{tabular}

As is seen in Table 9, after lesson every candidate teachers realized that every parallelogram is at the same time a trapezium. Although 6 candidate teachers knew the features of parallelogram and trapezium, they could not comprehend every parallelogram is at the same time a trapezium.

The findings of clinic interview with СT32 who is one of these candidate teachers are given below.

R: Is every parallelogram at the same time a trapezium?

CT32: Well, you asked this question before.

R: Yes.

CT32: I think, every parallelogram is at the same time a trapezium?

R: How? Explain please.

CT32: Both parallelogram and trapezium are rectangle. Two sides of trapezium are parallel, but all sides of parallelogram are parallel.

R: What do you mean saying all sides?

CT32: I mean opposite sides.

R: Okay, you can go on.

CT32: Both shapes must be closed chain.

R: Yes.

CT32: But, I am confused. Is every parallelogram at the same time a trapezium? I am not sure.

R: Think, again.

CT32: I am not sure. I cannot visualize it.

As is seen, although CT32 knew the features of the shapes, he had some problems about associating them. This is the student who gave wrong answer due to not knowing the features of the shapes before the Geometry Teaching Lesson. It is a good news that candidate teacher knew the features of the shapes even though he cannot gave the correct answer during after-lesson clinic interview.

\section{Conclusion and Discussion}

In this session, findings were discussed according to research problems. At first, it is aimed to determine how designed Geometry Teaching Lesson effect candidate teachers' Van Hiele Geometric Thinking Levels. As a result of the analysis, it is seen that before Geometry Teaching Lesson candidate teachers' Van Hiele Geometric Thinking Levels were pretty low (Table 4). In literature, it is also emphasized that candidate teachers' geometric thinking levels were lower than expected (Şahin, 2008; Durmuş, Toluk ve Olkun, 2002). After lesson, candidate teachers' geometric thinking levels were improved significantly and this improvement was meaningful according to t- test. That is, it can be said that designed Geometry Teaching Lesson had an effect on improving candidate teachers' Van Hiele Geometric Thinking Levels. However, after lesson, being no candidate teachers at Rigor Level draws attention. When the VHGTT is 
investigated, it is noticed that $5^{\text {th }}$ Level questions (21-25) are generally verbal and without using specific reasoning these questions could not be answered correctly. Although constructivist approach is adopted by Turkish Education System, it is known that the number of teachers who still teach their lesson with traditional approach is predominant.

On the other hand, it is a well-known fact that students studying to university exam are in tendency to learn the ways of solving problems more quickly via going to training center and they are directed to education system based on rote-learning. For that reason, the students coming to university after that kind of education system could not show the desired success to the reasoning questions. At second, it is aimed to find out the effect of Geometry Teaching Lesson to the candidate teachers' Van Hiele Geometric Thinking Test points. When the findings are examined, it is seen that before lesson, candidate teachers VHGTT points were in wide range and very low. After lesson, it is seen that the number of candidate teachers who got 7- 15 points were dominant. Furthermore, another remarkable finding is that there is no candidate teacher at fifth level, but there are some teachers who gave at least 3 correct answers to fifth level questions (21-25). It is judged by: as is explained in Data Analysis session, a candidate teacher who gives at least 3 correct answers at first level questions gets 1 point; a candidate teacher who gives at least 3 correct answers at second level questions gets 2 point; a candidate teacher who gives at least 3 correct answers at third level questions gets 4 point; a candidate teacher who gives at least 3 correct answers at fourth level questions gets 8 point; a candidate teacher who gives at least 3 correct answers at fifth level questions gets 16 point. In this case, the total point of candidate teacher who are at the fourth level is $1+2+4+8=15$. However, when Table 5 is examined, it is seen that 3 of candidate teachers got 23 points. It means that although these candidate teachers gave at least 3 correct answers to fifth level questions, they could not upgrade fifth level because of not giving at least 3 correct answers to lower levels questions. Giving correct answers to fifth level questions not lower level questions is an interesting situation. Candidate teachers stated that they could not exactly understand some of the questions during exam, some questions had two answers, and some questions did not have correct answer options. Durmuş, Toluk and Olkun (2002) indicated that they come across similar situation in their studies. They emphasized that the problem might arise from translating Van Hiele Test in Turkish. In this study, reason of this was investigated but finding out the reasons via detailed interviews with candidate teachers in another research can make a great contribution to the literature.

Finally, it is aimed to find out how Geometry Teaching Lesson has an effect on candidate teachers' answering clinic interview questions correctly. When the findings are examined, it is seen that pre- lesson remarkable part of candidate teachers gave wrong answer to this question: Is every parallelogram at the same time a trapezium? Generally, prelesson candidate teachers gave wrong answers due to imperfect geometry knowledge and not associating features of the shapes. After-lesson the number of candidate teachers giving correct answers is predominant. Even though 5 of the candidate teachers explained the features of parallelogram and trapezium correctly, they could not see the relations between them. When clinic interviews are generally evaluated, it can be said that there is a significant improvement in candidate teachers' geometric thinking levels in comparison with pre-lesson. When the literature is investigated, it is seen that there are a lot of studies propounding that well-designed geometry lesson can improve geometric thinking levels (Scally, 1991; Gigliotti, 1996; Bell, 1998; Breen, 2000; Toluk, Olkun and Durmuş, 2002; Özsoy and Kemankaşlı, 2004; Güven, 2006; Tutak and Birgin, 2008; Abdullah and Mohamed, 2008; Meng, 2009; İdris, 2009; Anapa et al., 2010). Consequently, it can be said that well- designed Geometry Teaching Lesson has an effect on improving candidate teachers' geometric thinking levels.

\section{Research Limitations}

This research is limited with 44 candidate mathematics teachers. Studying with lots of candidate teachers and forming different experimental and control groups can reveal impressive results while comparing their success.

\section{Recommendations}

It is seen that candidate teachers' Van Hiele Geometric Thinking Levels were lower than expected so designed Geometry Teaching Lesson was effective in improving their levels. Conducting similar researches for designing different lessons in order to improve candidate teachers' geometric thinking levels will be useful for comparing and finding out the most effective design. Besides, with the scope of this research testing designed lesson with different sample groups and sharing their results with the readers is important. If the same success can be determined in different sample groups, designed lesson can be suggested as an elective course at all faculty of education.

It is identified that with the scope of this research there are some problems causing Turkish form of Van Hiele Geometric Thinking Test so candidate teachers claimed that they could not understand some questions and some questions also have more than one answer. For that reason, it is important to present incoherent questions and their reasons of not being understood with performing extensive quantitative study. If the reasons of not being understood can be identified and necessary corrections can be done on Turkish version of questions, the rate of giving correct answer will be risen. 
One of the eye catchers in this research is that during pre-lesson, most of the candidate teachers gave wrong answers to the questions which were asked during the clinical interview. Although significant part of candidate teachers knew the features of the figures, they gave wrong answers as they had problems about linking features together. For that reason, it is not enough just teaching the features of the figures from primary school to university. These features should be linked together (associated with each other), their similarities and differences should be emphasized. In this way, students' geometric thinking levels can be improved by geometry teaching based on reasoning.

\section{References}

Abdullah, A. H., \& Mohamed, M. (2008). The use of interactive geometry software (IGS) to develop geometric thinking. Jurnal Teknologi, 49(E), 93-107. http://dx.doi.org/10.11113/jt.v49.212

Anapa, P., Bağdat, O., Girit, D., \& Karakoca, A. (2010). Dinamik geometri yazllımı ile geometri ögretiminin ögrencilerin Van Hiele geometri anlama düzeylerine etkisi. Paper presented at IX. Ulusal Fen Bilimleri ve Matematik Eğitimi Kongresi, İzmir: Dokuz Eylül Üniversitesi.

Baki, A. (2006). Kuramdan Uygulamaya Matematik Eğitimi. Trabzon: Derya Kitabevi.

Bal, A. P. (2012). Teacher candidates' geometric thinking levels and attitudes to geometry. Journal of Educational Sciences Research, 2(1), 17-34. http://ebad-jesr.com/

Battista, M. T. (2002). Learning geometry in a dynamic computer environment. Teaching Children Mathematics, 8 , 333-339.

Bell, M. D. (1998). Impact of an Inductive Conjecturing Approach in a Dynamic Geometry-Enhanced Environment. $\mathrm{Ph} . \mathrm{D}$. thesis, Georgia State University, ABD.

Breen, J. J. (2000). Achievement of Van Hiele level two in geometry thinking by eighth grade students through the use of geometry computer-based guided instruction. Ph.D. thesis, University of South Dakota.

Cohen, L., \& Manion, L. (1994). Research methods in education, Routledge, New York.

Creswell, J. W. (2008). Educational research planning, conducting and evaluating quantitative and qualitative research. International Pearson Merril Prentice Hall.

Creswell, J., \& Plano Clark, V. L. (2007). Understanding mixed methods research. In J. Creswell (Ed.), Designing and conducting mixed methods research (pp. 1-19). Thousand Oaks, CA: Sage.

Dindyal, J. (2007). The need for an inclusive framework for students' thinking in school geometry. The Montana Mathematics Enthusiast, 4(1), 73-83.

Durmuş, S., Toluk, Z., \& Olkun, S. (2002). Matematik öğretmenliği 1. sınıf öğrencilerinin geometri alan bilgi düzeylerinin tespiti, düzeylerin geliştirilmesi için yapılan araştırma ve sonuçları. Paper presented at $V$. Ulusal Fen Bilimleri ve Matematik Ĕgitimi Kongresi, Ankara, Bildiri Kitabı.

Eşme, İ. (2008). PISA 2006 sonuçlart ve Türkiye'de fen eğitimi, Radikal Gazetesi.

Gigliotti, M. R. (1996). A supplemental geometry unit to enhance eighth-grade students' Van Hiele thinking levels. Ph.D. Thesis, Columbia University, ABD.

Güven, Y. (2006). Farklı geometrik çizim yöntemleri kullanımının öğrencilerin başarı, tutum ve Van Hiele geometri anlama düzeylerine etkisi. (Unpublished master's thesis) Karadeniz Technical University, Trabzon.

Hurma, A. R. (2011). 8. sınıf geometri dersi çokgenler açı ünitesinde Van Hiele Modeline dayalı öğretimin öğrencinin problem çözme başarısına ve öğrenmenin kalıcılı̆̆ına etkisi. (Unpublished master's thesis) Atatürk University, Erzurum.

Idris, N. (2009). The impact of using geometers' sketchpad on Malaysian students' achievement and Van Hiele geometric thinking. Journal of Mathematics Education, 2(2), 94-107.

Johnson, R., \& Onwuegbuzie, A. (2004). Mixed methods research: A research paradigm whose time has come. Educational Researcher, 33(7), 14-26. http://dx.doi.org/10.3102/0013189X033007014

Lee, W. (2000). The Relationship between Students' Proof-Writing Ability and Van Hiele Levels of Geometric Thought in A College Geometry Course. Dissertation Abstract Index, 60(7), 246A.

MEB. (2000). İlköğretim okulu matematik dersi programı 5. Sinıflar. Milli Eğitim Basımevi, İstanbul.

Meng, C. C. (2009). Enhancing Students' Geometric Thinking Through Phase-Based Instruction Using Geometer's Sketchpad: A Case Study. Journal Pendidik dan Pendidikan, 24, 89-107. 
Okumuş, S. (2011). Dinamik Geometri Ortamlarının 7. Sinıf Öğrencilerinin Dörtgenleri Tanımlama ve Sinıflandırma Becerilerine Etkilerinin Incelenmesi. (Unpublished master's thesis), Karadeniz Technical University, Trabzon.

Olkun, S., \& Aydoğdu, T. (2003). Üçüncü Uluslararası Matematik ve Fen Araştırması (TIMSS) nedir? Neyi Sorgular? Örnek Geometri Soruları ve Etkinlikler. İlköğretim Online Dergisi, 2(1), 28-35.

Olkun, S., \& Toluk, Z. (2003). Matematik öğretimi. Anı Yayınc1lık, Ankara.

Özsoy, N., \& Kemankaşlı, N. (2004). Ortaöğretim öğrencilerini çember konusundaki temel hataları ve kavram yanilgıları. The Turkish Online Journal of Educational Technology-TOJET, 3(4), Article 19.

Regina, M. M. (2000). Enhancing geometric reasoning. Look Smart Find Articles, Online, Summer.

Şahin, O. (2008). Sinıf ögretmenlerinin ve sinıf ögretmeni adaylarının Van Hiele geometrik düşünme düzeyleri. (Unpublished master's thesis), Afyon Kocatepe University, Afyon.

Scally, S. P. (1991). The impact of experience in a LOGO learning environment on adolescems' understanding of angle: A Van Hiele based clinical assessments. Dissertation Abstracts International, 52(3).

Toluk, Z., Olkun, S., \& Durmuş, S. (2002). Problem merkezli ve görsel modellerle destekli geometri öğretiminin sınıf öğretmenliği öğrencilerinin geometrik düşünme düzeylerinin gelişimine etkisi. V. Ulusal Fen Bilimleri ve Matematik Ë̆itimi Kongresi, Ankara. Bildiri Kitabı.

Tutak, T. (2008). The effects of using concrete materials and dynamic geometry software on students' cognitive learning, attitudes, and understanding levels of Van Hiele geometry. Doctoral Thesis, Karadeniz Technical University, Trabzon, Turkey.

Tutak, T., \& Birgin, O. (2008). Dinamik Geometri Yazılımı ile Geometri Öğretiminin Öğrencilerin Van Hiele Geometri Anlama Düzeylerine Etkisi, 8. Uluslararası Eğitim Teknolojisi Konferansı, Eskişehir: Anadolu Üniversitesi.

Usiskin, Z. (1982). Van Hiele levels and achievement in secondary school geometry. The University of Chicago, Chicago.

Yayan, B., \& Berberoğlu, G. (2009). Uluslararası matematik ve fen çalışmasında (TIMSS 2007) Türk öğrencilerinin matematik başarısının modellenmesi. XVIII. Ulusal Eğitim Bilimleri Kurultayl, İzmir: Ege Üniversitesi Eğitim Fakültesi. 
Appendix: Van Hiele Geometric Thinking Test

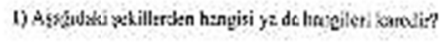
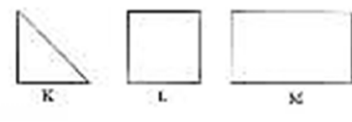

a) Srotece $\mathrm{K}$

b) Sulece 1

c) Stdros:

d) $\mathrm{L} v \mathrm{M}$

e) Bepsi

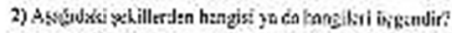
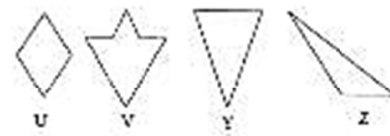

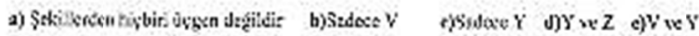

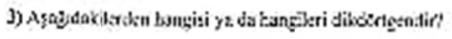
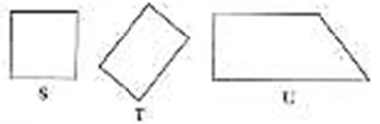

i) Srlose $S$

b) Sasote $T$

c) 5 roT

d) S ve I

e) Hord

4) Aspidaciledon tangisi yz da bangiltri karedir?
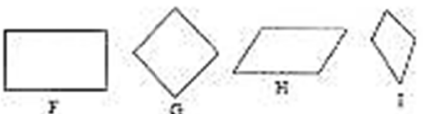

a) Iliębin

b) Sadece of

c) F res

d) Givel

8) Hexsi

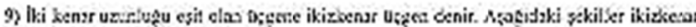

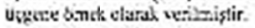

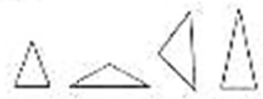

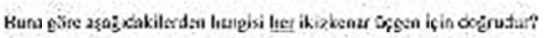

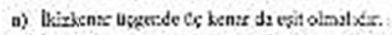

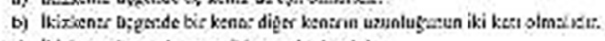

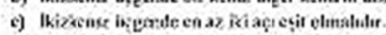

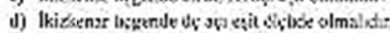

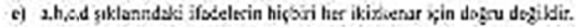

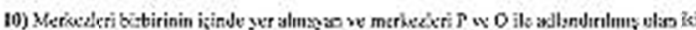

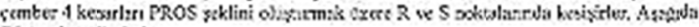
zciscnik vectilmił.it.
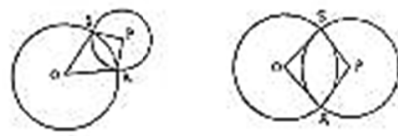

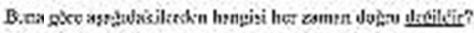

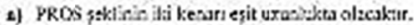

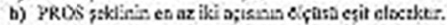

c) (PO] ve $[\mathrm{RS}]$ dik olscalt:

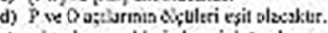

c) a,bc, d sosentklerin tepei dogrut.r.

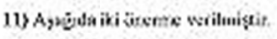

Önacne l: F sekli bir dzdertsendir.

Dieme z; F. gak: bir U; texte.

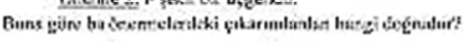

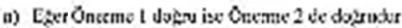

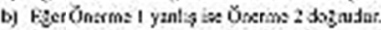

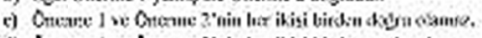

d) Oneme I ve Onesme 2 'nin her ikisi birden yonlıg ularras

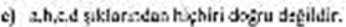

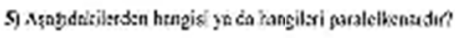

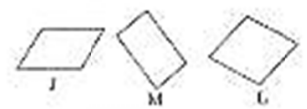

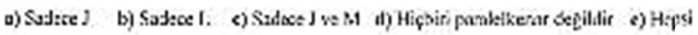

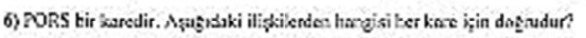

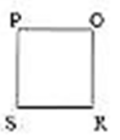

a) [RR] ve[RS] syn uzunluk:adir.

b) $|O S|$ w $|P R|$ tirbitini dik kes:-

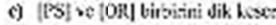

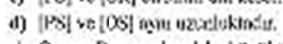

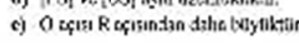

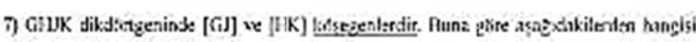

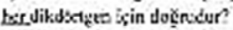

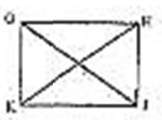

a) Dirr dik o,isi wadir.

b) Dxt kenถ⿻า veritur.

c) Kbyaytenleri esin uzunluktodis.

d) Kaşit kenurarı tait zunluktzdir.

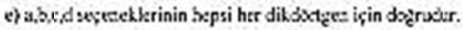

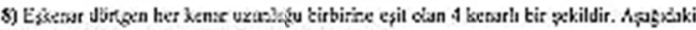

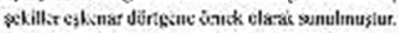

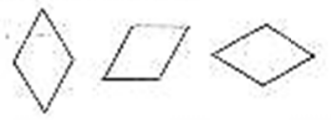

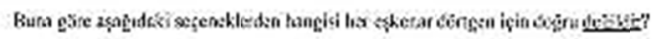

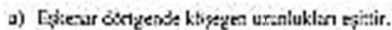

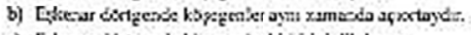

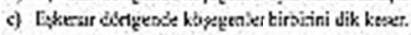

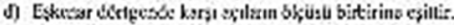

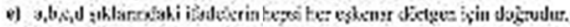

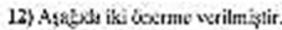

Onerme I: ABC ceseni aynu uraelson sabip of kecara sahiptic.

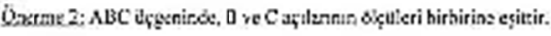

Buns gitre tu tenenmelerdeki çikmolerdan heceíisi doṣnobie?

a) Oxrene I ve Onerme 2 'nia har ihisi hirden deceru olamez.

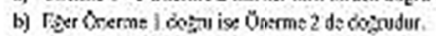

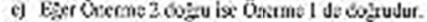

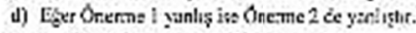

c) $a, b, c \in$ şıklaradan liçbiri dogra desilldir.

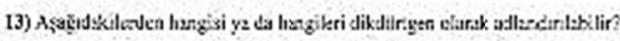

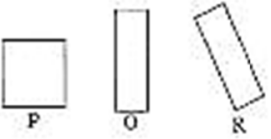

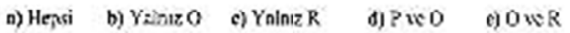

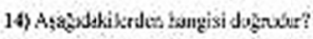

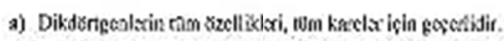

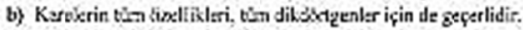

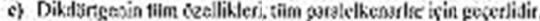

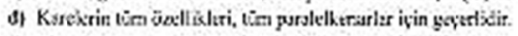

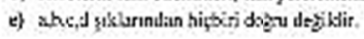

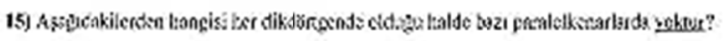

a) Karşıt kenz uxunluklan eşitlir

b) Köegen unbahlaklan eçirtir

c) Karayl kenztar birbirin: paraleldir

d) Karşıt aş:lır hirtirine eşittir

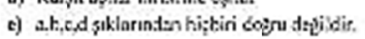

\section{$((c))$ EY}

This work is licensed under a Creative Commons Attribution 3.0 License. 